\title{
Traditional and modern expressions of Phulkari
}

\author{
MANDEEP KAUR, SANDEEP BAINS, SUMEET KANG GREWAL AND NEELAM GREWAL
}

Received: 01.05.2014; Revised: 01.10.2014; Accepted: 15.10.2014

See end of the paper for authors' affiliations MANDEEP KAUR

Department of Apparel and Textile Science, College of Home Science, Punjab Agricultural University, LUDHIANA (PUNJAB) INDIA

Email: mandeepfd@gmail.com
ABSTRACT : Handicrafts offer reflections to the artistic creativity rendered by the people of a region producing a traditional masterpiece even though moulded with the winds of time. These crafts serve as the roots of the ethnic fashions that shape the trends and innovations of the coming future. Phulkari craft is from the land of five rivers - Punjab which has experienced such transformation emerging out of the changing times and trends. The artefact being an important element of the cultural heritage of Punjab needs to be revitalized. The various traditional aspects of the craft need to be compared with its modern form to review all transformations. Documentation of both traditional and contemporary articles worked with Phulkari embroidery was undertaken to study the historical aspects and the modifications. The work was an attempt to preserve the essence of the craft serving the interest of the future generations.

KEY WORDS: Phulkari, Hand embroidery, Motifs, Traditional craft

- HOW TO CITE THIS PAPER : Kaur, Mandeep, Bains, Sandeep, Grewal, Sumeet Kang and Grewal, Neelam (2014). Traditional and modern expressions of Phulkari. Asian J. Home Sci., 9 (2) : 460-464. 